\title{
RADIKALISME AGAMA DAN POLITIK DEMOKRASI DI INDONESIA PASCA-ORDE BARU
}

\author{
Masdar Hilmy \\ Fakultas Tarbiyah dan Keguruan UIN Sunan Ampel \\ Jl. Ahmad Yani No. 117, Surabaya, Jawa Timur, 60237 \\ e-mail: masdar.hilmy@gmail.com
}

\begin{abstract}
Abstrak: Artikel ini menganalisis kemunculan radikalisme Islam di Indonesia pasca-Orde Baru dalam kaitannya dengan politik demokrasi serta implikasinya terhadap kebijakan negara atas radikalisme. Dengan menggunakan pendekatan politik-hukum, artikel ini berargumen bahwa kelompok radikal harus diperlakukan secara hati-hati dalam kerangka prinsip-prinsip demokrasi karena demokrasi harus menggaransi kebebasan berpendapat untuk semua. Dalam konteks ini, keberadaan radikalisme Islam tidak bisa dikekang atas alasan ideologis yang diwujudkan dalam bentuk kebijakan negara yang represif-antagonistik atas kelompok radikal. Kebijakan semacam ini dapat membawa pendulum ke arah kontra produktif bagi demokrasi itu sendiri karena kelompok radikal justru dapat memanfaatkan momentum tersebut untuk mengonsolidasikan dan mendiseminasikan ideologi radikalisme di kalangan masyarakat luas. Artikel ini merekomendasikan Undang-undang(UU) baru dan/atau addendum baru dalam rangka mengisi ruang kosong yang tidak disentuh oleh kedua UU tentang pemberantasan Tindak Pidana Terorisme sebelumnya.
\end{abstract}

\begin{abstract}
Religious Radicalism and the Politics of Democracy in Post New-Order Indonesia. This paper attempts at scrutinizing the emergence of Islamic radicalism in the post-New Order Indonesia and its mutual relationship with democratic politics as well as its implications to the state policy towards radicalism. This paper argues that the radical groups must be treated with deserve care in the framework of democratic principles on the ground that democracy must guarantee the idea of freedom of expression for all. In this context, the existence of Islamic radicalism cannot be curbed on an ideological basis manifested through an antagonist state policy towards radical groups. Such a policy, nevertheless, can swing the pendulum to a less productive to democracy itself. It may result in the consolidation and dissemination of radical ideology among the Muslim society within the framework of democracy. This paper recommends that a new act be necessary in order to fill the legal gap left by the two Acts on the counterterrorism policy.
\end{abstract}

Keywords: radikalisme Islam, demokrasi, Pancasila, UUD 1945 


\section{Pendahuluan}

Perkembangan dan pertumbuhan gerakan radikalisme pasca-Orde Baru tidak bisa dilepaskan dari pergantian rezim yang semakin terbuka. ${ }^{1}$ Kemunculan gerakan radikalisme Islam, baik yang klandestin—seperti Jemaah Islamiyah (J)—maupun yang terang-terangan— seperti Laskar Jihad, Laskar Jundulloh, FPI, MMI, HTI, dan lain-lain-merupakan dampak ikutan dari semakin terbukanya iklim politik dan demokrasi pasca-tumbangnya Orde Baru. Tanpa kehadiran era Reformasi, hampir dapat dipastikan kelompok-kelompok garis keras tersebut tidak akan berani muncul ke permukaan akibat represi politik yang dilakukan oleh rezim berkuasa. Keterbukaan politik yang diintroduksi oleh Presiden Habibie, penerus Presiden Soeharto, terbukti memberi semangat baru bagi kelompok masyarakat untuk menyuarakan berbagai aspirasi dan kepentingan politiknya secara bebas dan leluasa.

Pada masa ini pula, kelompok budaya dan politik yang tidak berafiliasi ke aliran keagamaan tertentu juga turut meramaikan ruang publik. Keterbukaan politik sebenarnya tidak saja membuka peluang bagi aliran atau ideologi keagamaan saja, tetapi juga gerakan antitesis terhadapnya. Sebagai contoh di Solo muncul kelompok paguyuban yang diberi nama PANGUNCI, kependekan dari Paguyuban Ngunjuk Ciu (Peguyuban Peminum Arak Lokal). Kelompok ini jelas bukanlah representasi dari aliran keagamaan. Bahkan, kemunculan kelompok semacam ini dapat dimaknai sebagai antitesis terhadap gerakan keagamaan yang marak di kota budaya ini. Seperti diketahui, kota ini menjadi persemaian bagi berbagai gerakan keagamaan garis keras seperti JI, Pondok Ngruki pimpinan Abu Bakar Ba'asyir, Jamaah Ansorut Tauhid (JAT) pimpinan Abu Bakar Ba'asyir, Majlis Tafsir Al-Qur'an (MTA) yang didirikan oleh Abdullah Tufail, dan FPIS (Forum Pemuda Islam Surakarta). ${ }^{2}$

Selain keran politik yang semakin terbuka, ada pula yang mengaitkan kemunculan gerakan radikalisme Islam dengan kondisi negara yang melemah. Serangkaian peristiwa kekerasan dan konflik bernuansa agama muncul pada saat rezim Orde Baru tumbang. Peristiwa bom di Jakarta (2000) dan Bali I (2002) juga muncul di awal-awal era Reformasi. Hal ini menunjukkan, proses delegitimasi kekuasaan negara seringkali memberikan ruang bagi kemunculan gerakan-gerakan tandingan di luar lembaga kenegaraan yang dimotori oleh aktor-aktor non-negara.

Tulisan ini akan menganalisis kemunculan gerakan radikalisme Islam dalam konteks politik demokrasi dan upaya penanggulangannya. Hal-hal yang akan dibahas adalah sejauhmana demokrasi memberi jaminan kebebasan berpendapat, dan berserikat atau berorganisasi; bagaimana sikap kelompok radikal terhadap demokrasi; bagaimana kebijakan

${ }^{1}$ Noorhaidi Hasan, Laskar Jihad: Islam, Militancy, and the Quest for Identity in Post-New Order Indonesia (Ithaca: Cornell Southeast Asia Program Publications, 2006), h. 13-25.

${ }^{2}$ Muhammad Wildan, "Mapping Radical Islam: A Study of the Proliferation of Radical Islam in Solo, Central Java," dalam Martin van Bruinessen (ed.), Contemporary Developments in Indonesian Islam: Explaining the "Conservative Turn" (Singapore: ISEAS, 2013), h. 190-223. 
negara terhadap kelompok radikal; bagaimana solusi dalam menangani gerakan radikalisme Islam di Indonesia dalam bingkai demokrasi?

\section{Jaminan Demokrasi}

Seperti disingggung di atas, rezim demokrasi memberikan ruang-ruang partisipatifegaliter bagi kelompok masyarakat untuk mengartikulasikan berbagai kepentingannya. ${ }^{3}$ Dalam rezim demokrasi, setiap warga negara memiliki hak yang sama untuk berpendapat dan berserikat sesuai dengan peraturan perundangan yang berlaku. Setiap warga negara juga memiliki posisi yang sama di muka hukum. Tidak ada salah seorang yang lebih istimewa dibanding lainnya. Artinya, sebuah rezim demokrasi harus meruangkan perbedaan kepada siapapun, sepanjang dibenarkan oleh paraturan perundangan yang berlaku. Demokrasi harus memberikan hak hidup kepada setiap warga negara, apapun latar belakang sosialbudaya dan agamanya, termasuk musuh kita. Inilah keutamaan dan keistimewaan yang dimiliki oleh demokrasi yang tidak dimiliki oleh bentuk-bentuk rezim politik lainnya. Dalam rezim demokrasi, hak-hak semacam ini dijamin oleh konstitusi. Pelanggaran terhadap salah satu dari hak tersebut merupakan sebentuk pelanggaran konstitusi yang dapat diancam dengan hukuman. ${ }^{4}$

Di sebuah rezim yang tidak menganut demokrasi, tidak setiap warga negara diperlakukan sama di muka hukum. Warga negara juga tidak dibiarkan menikmati hak-hak sipil seperti hak bersuara, hak berpendapat, hak berserikat, hak beragama, hak rasa aman, dan hak-hak lainnya. Di sejumlah negara "disipliner" seperti Korea Selatan dan Korea Utara, Singapura, dan Tiongkok, warga negara tidak diberi kebebasan sipil untuk menyuarakan aspirasi dan kepentingannya. ${ }^{5}$ Yang memotivasi mengapa negara sering bertindak represif kepada warganya adalah karena aktor-aktor negara memperlakukan sektor ekonomi lebih istimewa daripada kebebasan sipil. Kebebasan sipil, terlebih yang bersifat ekstrem, dianggap dapat mengganggu konsentrasi kinerja negara dalam menjalankan program-program pembangunannya. Itulah sebabnya negara-negara "disipliner" di atas memiliki tingkat stabilitas pembangunan dan pertumbuhan yang baik, sekalipun hal itu dilakukan di luar kerangka rezim demokrasi. ${ }^{6}$

${ }^{3}$ David Beetham, "The Quality of Democracy: Freedom as the Foundation," dalam Journal of Democracy, Vol. 15, No. 4 (October 2004), h. 61-75.

${ }^{4}$ Ibid.

${ }^{5}$ Amartya Sen, "Democracy as a Universal Value," dalam Journal of Democracy, Vol. 10, No. 3 (1999), h. 5.

${ }^{6}$ Kenyataan semacam inilah yang dapat menjelaskan mengapa negara-negara "disipliner" memiliki tingkat kemajuan ekonomi yang mengagumkan dibanding dengan negara-negara demokrasi yang pada umumnya stagnan dalam perkembangan ekonomi. Lebih jauh tentang hubungan antara ekonomi dan demokrasi, lihat, Adam Przeworski, et. al., Sustainable Democracy (Cambridge: Cambridge University Press, 1995). 
Bagaimana dengan Malaysia? Negara jiran ini agak berbeda dengan negara-negara "disipliner" sebagaimana disebutkan di atas, terutama dalam menangani masalah kehidupan beragama. Malaysia memang tidak bisa disebut sebagai negara demokrasi dalam pengertian generik seperti Indonesia. Sama-sama meruangkan perbedaan bagi penganut agama yang berbeda untuk menjalankan keyakinan dan agamanya bukan berarti Indonesia dan Malaysia memiliki derajat yang sama dalam penerapan demokrasi. Malaysia menindak tegas terhadap kelompok atau individu yang dipersepsi akan merongrong kewibawaan pemerintah, termasuk terhadap kelompok radikal, sebuah fitur yang tidak ada di Indonesia.

Di negeri ini, demokrasi hampir memberikan ruang seluas-luasnya bagi setiap warga negara untuk melakukan apapun. Demokrasi yang dimaknai dan dipraktikkan di negeri ini sungguh jauh lebih "liar" dibanding demokrasi yang ada di Malaysia. Dengan Undangundang keamanannya (Internal Security Act/ISA), Malaysia dapat menindak siapa pun yang dicurigai dapat membahayakan kehidupan publik. ${ }^{7}$ Dengan UU ini, pemerintah memiliki otoritas untuk menahan siapapun yang dianggap berbahaya tanpa melalui proses peradilan terlebih dahulu. UU ini membuat kelompok garis keras melarikan diri ke negara-negara lain, sebagian melarikan diri ke Indonesia seperti Noordin Mohd. Top dan Azhari yang telah tewas di tangan Densus 88.

Memasuki Era Reformasi, penataan kehidupan agama di ruang publik memang jauh lebih longgar dibanding era Orde Baru. Pada masa Soeharto, Indonesia menerapkan UU anti-subversi yang sering disalahgunakan untuk tujuan-tujuan represif melalui Penetapan Presiden Republik Indonesia No 11 Tahun 1963 tentang Pemberantasan Kegiatan Subversi. ${ }^{8}$ Akibatnya, UU ini seringkali dianggap membelenggu kemerdekaan dan kebebasan publik. Seiring dengan tumbangnya Orba dan pergantian rezim ke era Reformasi, UU ini menjadi salah satu yang diaspirasikan untuk dicabut. Presiden BJ. Habibie, sebagai penerus Presiden Soeharto, mengambil inisiatif pencabutan UU tersebut. ${ }^{9}$ Pencabutan UU tersebut terbukti menjadi pintu masuk bagi kelompok aliran dan keagamaan untuk kembali aktif setelah sekian lama tiarap. Pada saat itulah berbagai ormas radikal bermunculan. Mereka memanfaatkan kebebasan yang diberikan oleh Presiden Habibie sebagai kendaraan untuk memasarkan gagasan-gagasan keagamaannya yang radikal.

Untuk melihat sejauhmana demokrasi memberikan jaminan kepada warga negara dalam berpendapat, berserikat dan berkumpul, ada baiknya dirujuk pada dua ukuran ukuran normatif-konstitusional yang berupa peraturan perundangan yang berlaku di

${ }^{7}$ Human Rights Watch, "In the Name of Security: Counterterrorism and Human Rights Abuses under Malaysia's Internal Security Act," Vol. 16, No. 7 (Mei 2004).

${ }^{8}$ Hans Thoolen, Indonesia and the Rule of Law: Twenty years of "new order" government: A Study (London: Pinter Pub Ltd., 1987).

${ }^{9}$ Lebih jauh mengenai pencabutan UU Anti-subversi oleh Presiden B.J. Habibie. Lihat, misalnya, Nadirsyah Hosen, "Human Rights and Freedom of the Press in the post-Soeharto Era: A Critical Analysis," dalam Asia Pacific Journal on Human Rights and the Law, Vol. 3, No. 2 (2002), h. $1-104$. 
Indonesia; dan ukuran empiris-sosiologis berupa pengukuran sejumlah institusi pengukur yang melakukan survey periodik tentang indeks demokrasi, indeks kebebasan dan semacamnya.

Secara normatif, Indonesia mengadopsi tatanan kenegaraan yang mengakomodasi berlakunya prinsip-prinsip demokrasi seperti kebebasan berserikat dan berkumpul, kebebasan berpendapat, kebebasan beragama, kebebasan memilih secara politik, dan seterusnya. ${ }^{10}$ Kemerdekaan-kemerdekaan semacam ini sudah diamanatkan oleh konstitusi Indonesia seperti UUD 1945 yang diperkuat oleh UU No. 9 Tahun 1998 tentang Kemerdekaan Menyampaikan Pendapat di muka umum. Pasal 28E ayat (3) UUD 1945 mengafirmasi kebebasan berpen-dapat: "Setiap orang berhak atas kebebasan berserikat, berkumpul, dan mengeluarkan pendapat." Sementara itu, Pasal 2 ayat (1) UU No. 9 Tahun 1998 menyatakan bahwa "Setiap warga negara, secara perorangan atau kelompok, bebas menyampaikan pendapat sebagai perwujudan hak dan tanggung jawab berdemokrasi dalam kehidupan bermasyarakat, berbangsa dan bernegara."

Kebebasan berpendapat, berserikat dan berkumpul juga merupakan bagian dari Hak Asasi Manusia (HAM) yang diafirmasi oleh Deklarasi Universal Hak Asasi Manusia (DUHAM) pasal 19 yang menegaskan bahwa: "Setiap orang berhak atas kebebasan berpendapat dan berekspresi, dalam hal ini mencakup kebebasan untuk berpegang teguh pada pendapat tertentu tanpa mendapatkan gangguan, dan untuk mencari, menerima dan menyampaikan informasi dan ide/gagasan melalui media apa saja tanpa ada batasan." Meskipun ada jaminan untuk bebas berpendapat dan berekspresi, pelaksanaan hak tersebut bukanlah tidak terbatas. Pada pasal 29 ayat 2 pada deklarasi yang sama ditegaskan bahwa: "dalam menjalankan hak-hak dan kebebasan-kebebasannya, setiap orang harus tunduk hanya pada pembatasan-pembatasan yang ditetapkan oleh undang-undang dengan maksud sematamata untuk menjamin pengakuan dan penghormatan terhadap hak-hak dan kebebasankebebasan orang lain dan untuk memenuhi persyaratan aspek moralitas, ketertiban dan kesejahteraan umum dalam suatu masyarakat yang demokratis."11

Dalam konteks Indonesia, penerapan hak berpendapat, berserikat dan berkumpul tidak selalu berjalan mulus. Sebagai bangsa Timur, jenis dan makna kebebasan yang dipahami oleh bangsa Indonesia pasti tidak persis sama sebagaimana dipahami di kalangan masyarakat Barat yang individualistis dan liberal. ${ }^{12}$ Kebebasan dalam konteks Timur tentu saja meniscayakan perimbangan-perimbangan yang dapat mengendalikan bandul kebebasan tersebut agar tidak berjalan tanpa batas. Hak-hak dan kebebasan dimaksud dibatasi oleh kerangka nilai-nilai dasar yang berbasis pada alasan-alasan kolektifisme sosiologis yang senantiasa mengedepankan pada ungkapan "tepo seliro" (Jawa, tenggang rasa) dengan cara mempertimbangkan lingkungan sekitar sebagai bahan penting dalam

\footnotetext{
${ }^{10}$ Daniel S. Lev, "Judicial Authority and the Struggle for an Indonesian Rechtsstaat," dalam Law and Society Review, Vol. 3, No. 1 (Autumn, 1978), h. 37-71.

${ }^{11}$ Lihat: http://www.un.org/en/documents/udhr/.

${ }^{12}$ Hans Blokland, Freedom and Culture in Western Society (London: Routledge, 1997), h. 47.
} 
mengekspresikan kebebasan dimaksud. Dalam konteks inilah, bangsa Indonesia mengenal ungkapan "kebebasan seseorang dibatasi oleh kebebasan orang lain"; "tidak ada kebebasan tanpa batas," dan semacamnya. ${ }^{13}$

Di samping ukuran-ukuran normatif di atas, kebebasan juga dapat dilihat dari ukuranukuran empiris. Hal demikian dapat dilakukan melalui lembaga-lembaga pengukuranbaik di tingkat nasional maupun internasional-yang secara periodik mengukur tingkat kebebasan di negeri ini. Salah satu alat pengukuran untuk mengevaluasi kinerja demokrasi sebuah negara adalah dengan melihat indeks demokrasi (democracy index). Salah satu pengukuran indeks demokrasi dilakukan oleh the Economist Intelligence Unit yang mengevaluasi kondisi demokrasi di 167 negara. ${ }^{14}$ Indeks tersebut berdasarkan pada 60 indikator yang dikelompokkan ke dalam lima kategori. Di antara aspek-aspek demokrasi yang diukur adalah pluralisme, kebebasan sipil (civil liberties), dan budaya politik. Pengukuran tersebut mengklasifikasikan negara-negara yang diukur ke dalam empat kelompok utama: full democracies [bernilai 8,0-10]; flawed democracies [bernilai 6,0-7,9]; hybrid regimes [bernilai 4,0-5,9], dan authoritarian regimes [bernilai 0-3,9]. Indeksasi demokrasi tersebut pertama kali dilakukan pada 2006 yang kemudian di-update pada 2008, 2010 dan tahun-tahun setelahnya.

Dari seluruh negara yang diukur tingkat demokrasinya, negara yang masuk dalam kategori full-democracies berjumlah 24 yang mayoritas dihuni oleh negara-negara Barat (Eropa, Australia dan Amerika Utara). Indonesia berada pada posisi 49 sebagai negara flaweddemocracies yang diapit oleh Trinidad \& Tobago (ranking 48) dan Kroasia (ranking 50). Negara-negara yang masuk kategori ini berjumlah 52, mayoritas dihuni oleh negara-negara Asia, Afrika dan Amerika Latin. Di antara negara tetangga yang masuk kategori ini adalah Timor-Leste (peringkat 46), Malaysia (peringkat 65), Singapura (peringkat 75), dan Filipina (peringkat 53). Sementara itu, negara-negara kawasan Timur Tengah banyak menghuni kategori ketiga (hybrid regimes) dan keempat (authoritarian regimes) yang berjumlah 91. Misalnya, Saudi Arabia berada di posisi 161, Syria (163), Iran (158), Libya (119), Yaman (149), dan seterusnya. Dua kategori terakhir merupakan tingkat terburuk dalam penerapan demokrasi.

Parameter lain yang biasanya digunakan untuk mengukur tingkat demokrasi di sebuah negara adalah Rumah Kebebasan (Freedom House) yang bermarkas di Washington D.C. ${ }^{15}$ Rumah Kebebasan mengklasifikasikan negara-negara yang ada di dalamnya ke dalam tiga kategori: fully free, partly free, dan not free. Berdasarkan survey yang dilakukan oleh Rumah Kebebasan pada 2015, Indonesia diklasifikasikan sebagai partly free. Posisi ini dihuni oleh Indonesia dalam kurun dua tahun terakhir. Posisi ini patut disayangkan karena

${ }^{13}$ Masdar Hilmy, “"Quo-Vadis" Kebebasan Beragama?," dalam Kompas, 1 Maret 2011, h. 7.

${ }^{14}$ Lihat, Laza Kekic, "The Economist Intelligence Unit's index of democracy," diakses dari http://www.economist.com/media/pdf/DEMOCRACY_INDEX_2007_v3.pdf, 14 Juni 2015.

${ }^{15}$ Lihat https://freedomhouse.org 
selama empat tahun berturut-turut (2010-2013) Indonesia sudah masuk dalam jajaran negara yang fully free. Sementara itu, negara tetangga Malaysia selalu menempati kategori partly free, bersama Filipina, Singapura, dan Thailand.

Secara nasional, terdapat alat pengukuran lain atas demokrasi yang dilakukan oleh Program Pembangunan PBB (UNDP) yang mengukur demokrasi setiap tahun. Aspekaspek yang diukur oleh UNDP mencakup tiga hal: civil liberties, political rights, dan democratic institutions. ${ }^{16} \mathrm{Jika}$ aspek pertama meliputi hak-hak sipil warga seperti kebebasan beragama, aspek kedua mencakup hak warga untuk memilih dan dipilih dalam sistem pemilihan umum, dan aspek ketiga mencakup lembaga-lembaga yang secara langsung menopang dan menumbuhkan semangat demokrasi seperti parpol. Dilihat dari parameter UNDP, penerapan demokrasi di negeri ini semakin menunjukkan trend penurunan indeks dari tahun 2009-2012. Pada 2009, indeks demokrasi Indonesia mencapai 67,30, kemudian mengalami penurunan menjadi 63,17 (2010), 65,48 (2011), dan 62,63 (2012).

Demikianlah, dua parameter demokrasi yang dapat dijadikan sebagai patokan dalam melihat kecenderungan naik-turunnya demokrasi di Indonesia. Dari segi apapun, Indonesia sebenarnya cukup suportif terhadap tumbuh dan berkembangnya demokrasi. Sebab, meminjam Robert Hefner, Indonesia tidak memiliki "kejanggalan peradaban" (civilizational malady) yang dapat menghambat pertumbuhan demokrasi. ${ }^{17}$ Tidak seperti banyak diasumsikan oleh kelompok incompatibility thesis, faktor agama-terutama Islam-tidak terbukti menjadi penghambat bagi kehidupan demokrasi. ${ }^{18}$ Bahkan, sebaliknya, faktor agama memberikan andil cukup signifikan dalam penerapan demokrasi dalam kehidupan berbangsa dan bernegara. Melalui ormas-ormas Islam moderat, terutama NU dan Muhammadiyah, nilai-nilai agama seperti toleransi, keterbukaan, penghormatan terhadap nilainilai kemanusiaan, keadilan dan kesederajatan dapat terjaga dengan baik dan dapat menumbuhkan semangat berdemokrasi di republik ini.

\section{Sikap Kaum Radikal terhadap Demokrasi}

Persoalannya adalah, kelompok radikal yang diuntungkan oleh sistem politik demokrasi memiliki hasrat yang tidak baik terhadap demokrasi. Mayoritas kelompok radikal mengusung ideologi islamis yang dikampanyekan kepada seluruh anggota masyarakat untuk meng-

${ }^{16}$ Lihat http://www.id.undp.org.

${ }^{17}$ Robert W. Hefner, Civil Islam (Princeton: Princeton University Press, 2000), h. 216.

${ }^{18}$ Incompatibility thesis dikemukakan oleh sejumlah ilmuwan politik esensialis yang melihat budaya berbasis agama sebagai entitas yang tertutup yang memungkinkan terjadinya benturan antarbudaya (clash of civilizations) di ujung pertemuan antarbudaya yang berbedabeda. Menurut kelompok ilmuwan ini, Islam, baik sebagai agama maupun sistem budaya, diasumsikan tidak akan bisa menerima demokrasi karena keduanya tidak compatible, bahkan di antara keduanya akan terjadi "benturan peradaban." Lihat, misalnya, Samuel P Huntington, The Clash of Civilization and the Remaking of World Order (New York: Penguin Books, 1996). 
gantikan sistem demokrasi yang diangap berasal dari Barat. Bagi mereka, sistem demokrasi jelas tidak mewakili Islam karena agama ini tidak pernah mengenal istilah demokrasi. Demokrasi dianggap sebagai hasil ciptaan akal budi manusia yang diperlakukan lebih istimewa ketimbang agama. Inilah yang oleh kalangan radikal digambarkan sebagai "pemberontakan atas kekuasaan Tuhan" (the revolt against God's sovereignty) ${ }^{19}$ Sekalipun mereka diuntungkan oleh iklim demokrasi di Indonesia, namun agenda pergerakannya adalah untuk menumbangkan demokrasi itu sendiri, baik melalui kekerasan maupun jalan damai, yang dilakukan secara radikal-revolusioner.

Memang respons dan penolakan kelompok radikal terhadap demokrasi cukup bervariasi; dari yang paling lunak hingga yang paling ekstrem. Kelompok paling lunak tidak secara terangterangan menghujat sistem demokrasi, tetapi secara halus membungkus argumentasi penolakannya melalui analisis dan kajian empiris di belahan dunia Barat dengan mengupas borok-borok sistem demokrasi, seperti pencaplokan wilayah Muslim, pembantaian kaum Muslim, kebusukan kapitalisme, perlakuan diskriminatif terhadap kaum Muslim minoritas di sejumlah negara Barat, hingga isu-isu moralitas seperti tradisi seks bebas, aborsi, judi, alkohol, dan semacamnya. ${ }^{20}$ Sekalipun mereka mengecam demokrasi, tetapi mereka tidak segan-segan untuk menggunakan argumentasi demokrasi dalam rangka mempertahankan eksistensi mereka. Hal demikian dilakukan bukan karena persetujuan atau dukungannya terhadap demokrasi, tetapi semata-mata sebagai taktik untuk mempertahankan eksistensi mereka sendiri dalam menghadapi serangan "musuh-musuh" mereka.

Sementara itu, di kalangan kelompok radikal ekstrem, penolakan terhadap demokrasi merupakan harga mati dan tidak jarang dilakukan melalui cara-cara kekerasan. Tidak seperti kelompok radikal "lunak" yang cenderung menggunakan argumentasi rasional dalam menolak demokrasi, mereka hampir selalu menggunakan argumentasi normatifteologis dalam melakukan hal yang sama. Menurut kelompok radikal ekstrem, istilah demokrasi tidak akan dijumpai dalam teks suci-Al-Qur'an dan hadis-maupun tradisi kesarjanaan Muslim lainnya. Demokrasi adalah sebentuk bidah yang dibangun di atas pemikiran manusia untuk menurutkan segala nafsu syahwatnya.

Di Indonesia, penolakan kaum radikal terhadap sistem demokrasi ditunjukkan melalui keengganan mereka berjuang melalui sistem parpol. ${ }^{21}$ Bagi mereka, keterlibatan dalam sistem partai politik berarti mereka melegitimasi sistem demokrasi yang mereka tolak. Konsekuensinya, program amar makruf nahi munkar yang mereka jalankan tidak bisa

${ }^{19}$ Baca, misalnya, Bruce B. Lawrence, Defenders of God: The Fundamentalist Revolt against the Modern Age (San Francisco: Harper \& Row, 1989. Lihat juga, Ahmad S. Mousalli, Radical Islamic Fundamentalism: The Ideological and Political Discourse of Sayyid Qutb (Beirut: American University of Beirut, 1992).

${ }^{20}$ Masdar Hilmy, Islamism and Democracy in Indonesia: Piety and Pragmatism (Singapore: ISEAS, 2010), h. 153-135-152.

${ }^{21}$ Ibid., h. 153-165. 
disuarakan melalui jalur-jalur politik formal, melainkan melalui media sosial-kemasyarakatan seperti selebaran, tabloid, internet, dan kajian-kajian terbatas di kalangan mereka. Oleh karena itu, selama ini kelompok radikal tidak berada di belakang PERDA Syariah yang sempat menjamur di beberapa daerah seperti Aceh dan Sulawesi Selatan. ${ }^{22}$ Mereka hanya menjadi kelompok penekan yang sepenuhnya beroperasi di luar lingkaran sistem politik formal. Kemunculan PERDA antimiras, misalnya, dimotori oleh parpol-parpol yang selama ini berkompetisi di jalur formal dan bukan semuanya berasal dari parpol-parpol Islamis atau berbasis massa Muslim.

Dalam menjalankan aksi amar makruf nahi munkar, kelompok radikal ekstrem bahkan tidak segan-segan menggunakan cara-cara kekerasan seperti penyisiran tempattempat hiburan, penutupan paksa, penghancuran fasilitas, dan pembakaran. Kelompok radikal yang sering menggunakan cara-cara kekerasan di antaranya adalah FPI yang dipimpin oleh Habib Rizieq Syihab. Ormas ini tidak jarang terlibat bentrok dengan kelompokkelompok lain yang dianggap menghalangi penegakan syariat Islam. Pada kasus RUU Pornografi dan Pornoaksi, misalnya, kelompok ini terlibat bentrok secara fisik dengan para penentang RUU tersebut di Jakarta beberapa tahun lalu. Di Solo, kelompok radikal yang melakukan kekerasan didominasi oleh kelompok lokal seperti FPIS.

Fenomena terakhir adalah kemunculan sejumlah pendukung gerakan Islamic State of Iraq and Sham (ISIS/NIIS) yang terlihat secara sporadis di beberapa daerah seperti Sukoharjo, Malang, Tangerang, Surabaya, dan lain-lain. ${ }^{23}$ Bentuk dukungan yang mereka berikan berupa penggalangan bantuan uang dan pengiriman mujahid yang akan membantu para pejuang ISIS di wilayah konflik. Ketertarikan WNI yang bergabung dengan para pejuang ISIS didorong bukan saja oleh faktor ideologis, tetapi juga ekonomi melalui iming-iming gaji bulanan dan jaminan kesejahteraan bagi keluarga pejuang. Hingga kini, sejumlah lebih dari 500 WNI terdeteksi berada di wilayah konflik berjuang bersama-sama militan NIIS. Beberapa saat yang lalu, sebanyak 16 orang WNI diketahui hendak menyeberang ke wilayah Suriah melalui Turki, tetapi berhasil digagalkan oleh otoritas setempat. Mereka pun dipulangkan ke Indonesia.

Kenyataan gerakan radikal di Indonesia dan juga di negara-negara lain mengingatkan pada teori "jebakan demokrasi" (democracy trap). ${ }^{24}$ Yakni, rezim demokrasi dimanfaatkan oleh kelompok radikal untuk menjalankan aksinya untuk merebut politik-kekuasaan pada ujung pergerakannya. Memang sejumlah kelompok radikal tidak mau terlibat dalam

${ }^{22}$ Informasi lebih detail tentang bagaimana peran kelompok radikal dalam pembuatan PERDA Syariah, lihat, misalnya, Melissa Crouch, "Religious Regulations in Indonesia: Failing Vulnerable Groups," dalam Review of Indonesian and Malaysian Affairs, Vol. 43, No. 2 (2009), h. 53-103.

${ }^{23}$ Masdar Hilmy, "Genealogi dan Pengaruh Ideologi Jihadisme Negara Islam Iraq dan Suriah (NIIS) di Indonesia," dalam Teosofi, Vol. 4, Nomor 2 (Desember 2014), h. 404-428.

${ }^{24}$ Lihat, Graham E. Fuller, The Democracy Trap: the Perils of the Post-Cold War World (Boston: Dutton, 1992). 
hingar-bingar sistem politik praktis. Tetapi hal demikian bukan berarti mereka enggan memegang tampuk kekuasaan tertinggi di sebuah negara. Pada kenyataannya, mereka tetap berhasrat merebut kekuasaan melalui cara-cara mereka sendiri. Jika tidak dengan cara damai, maka dengan cara kekerasan. Kampanye damai yang dilakukan oleh mereka, pada saat-saat tertentu akan menyentuh titik jenuh yang dapat memaksa mereka untuk beralih ke cara-cara kekerasan jika kondisi menghendaki demikian. Bagi mereka, politics does matter. Politik adalah manifestasi tertinggi dari cara mereka melakukan transformasi radikal melalui amar makruf nahi munkar. Dengan politik-kekuasaan semua program akan dapat dijalankan secara otoritatif.

Jalan menuju tampuk kekuasaan ditempuh melalui strategi "ekstra-perlementer," yakni melalui cara-cara persuasif melalui kegiatan-kegiatan dakwah sosial-kemasyarakatan dan pengajian. Strategi sosial-kemasyarakatan ditempuh oleh kelompok radikal karena upaya mengislamkan negara melalui strategi "intra-parlementer" selalu berakhir dengan kegagalan. ${ }^{25}$ Kegagalan demi kegagalan inilah yang memaksa mereka beralih pada strategi lain yang relatif tidak terjangkau oleh aparatus politik-kenegaraan, yaitu strategi sosialkemasyarakatan. Mereka berkeyakinan bahwa ajakan ke arah ideologi radikal yang mereka jalankan kepada masyarakat luas pada akhirnya akan membuahkan hasil. Strategi semacam ini menempatkan individu sebagai agen yang akan menciptakan matarantai jejaring gerakan radikalisme di tingkat sosial. Ketika seluruh anggota masyarakat telah "terislamkan," maka mereka tinggal membutuhkan satu langkah saja menuju perebutan kekuasaan.

\section{Kebijakan terhadap Radikalisme}

Bagaimana negara menghadapi kelompok radikal, baik yang lunak maupun yang ekstrem, baik yang klandestin maupun terang-terangan? Pengembangan wacana ideologi radikal, sebagai bagian dari kebebasan berpendapat, jelas tidak bisa dimusnahkan oleh aparat negara. Pemusnahan kelompok radikal sebagaimana dilakukan oleh Malaysia jelas akan berpengaruh terhadap indeks kebebasan dan demokrasi yang setiap tahun selalu di-update. Memang harus diakui bahwa era reformasi merupakan saat yang paling menguntungkan bagi kelompok-kelompok radikal untuk mengampanyekan dan menjalankan aktivitas ideologisnya. Hal semacam ini tidak mungkin terjadi pada masa Orde Baru ketika negara bertindak represif terhadap kelompok-kelompok ekstrem, baik yang berafiliasi keagamaan maupun politik. Sebagai akibatnya, ormas-ormas radikal secara terbuka berani mengkampanyekan sikap anti-Pancasila dan menyatakan hendak menggantikannya dengan sistem Islam seperti khilafah dan syariah. Pancasila, demokrasi dan semacamnya dianggap sebagai Taghut, ciptaan manusia yang sudah menjadi sesembahan. ${ }^{26}$

\footnotetext{
${ }^{25}$ Olivier Roy, The Failure of Political Islam (Massachusetts: Harvard University Press, 1996).

${ }^{26}$ Lihat, misalnya, "Ustadz Ba'asyir: Indonesia Berhukum Thaghut, Umat Islam Dilarang Patuh," dalam Voa-islam, 15 Agustus 2013 (www.voa-islam.com, diakses 14 Juni 2015).
} 
Namun demikian, sikap demokrasi terhadap kelompok radikal memang ibarat buah simalakama; maju kena, mundur kena. ${ }^{27}$ Menindak kelompok kritis jelas akan menggerus kualitas demokrasi itu sendiri. Jika mereka tidak ditindak jelas akan merongrong demokrasi dari dalam, bahkan membunuhnya. Wacana negara khilafah dan syariah sebagai imajinasi negara ideal di satu sisi, dan wacana anti-Pancasila dan anti-demokrasi di sisi lain, seolah bebas berseliweran di ruang publik. Wacana dan ideologi radikal bahkan tidak jarang mampu memukau kaum terpelajar yang berprofesi sebagai ilmuwan, dosen, guru dan semacamnya. ${ }^{28}$ Namun demikian, negara tidak memiliki kapasitas untuk membelenggu wacanawacana semacam ini. Jika negara bertindak represif, maka dapat dipastikan pergerakan pendulum demokrasi akan berjalan ke arah negatif. Dalam konteks ini, negara baru dibolehkan melakukan intervensi ketika efek wacana tersebut terjadi, semisal ketika terjadi kekerasan yang melibatkan kelompok radikal. Hal ini terjadi karena negara tidak boleh membungkam wacana-wacana radikalisme sekalipun aparat keamanan negara (intelijen) berhasil mengendus rencana kekerasan tersebut. Inilah dilema yang dihadapi oleh negara demokrasi dalam menangani masalah radikalisme.

Kompleksitas lainnya muncul akibat penerapan demokrasi adalah terkait dengan politik elektorat. Rezim demokrasi yang diadopsi di Indonesia menghasilkan konsekuensikonsekuensi politik yang tidak pernah terjadi sebelumnya. Salah satu di antara konsekuensi tersebut adalah keterikatan antara political suffrage atau basis elektorat dengan negara yang dimediasi oleh aktor-aktor negara seperti pemerintah dan anggota parlemen. Dalam konteks ini, kebijakan negara seringkali mengikuti aspirasi atau keinginan mayoritas publik. Penanganan yang terlalu ketat terhadap kelompok radikal dapat menyebabkan pergerakan pendulum elektorat pada penggerusan suara di tingkat basis elektorat. Akibatnya, aktor-aktor negara seringkali tidak bisa bertindak netral atas nama negara. Kondisi semacam inilah yang dihadapi oleh agen-agen negara dalam kasus-kasus kekerasan agama yang melibatkan kelompok radikal di sejumlah daerah di Indonesia. Mereka tidak kuasa menghadapi tekanan politik yang menghendaki pemihakan terhadap kelompok-kelompok tertentu yang memiliki daya tawar politik di tingkat akar rumput.

Dalam banyak kasus, agen-agen negara bahkan terlibat—baik secara terbuka maupun diam-diam. Kenyataan ini merefleksikan hadirnya state favoritism dalam kebijakan negara

\footnotetext{
${ }^{27}$ Lihat, misalnya, Lawrence C. Reardon, "Interpreting Political Islam's Challenge to Southeast Asia: International Terrorism, Nationalism, and Rational Choice," dalam William Crotty (ed.), Democratic Development and Political Terrorism: The Global Perspective (Florida: Northeastern University Press, 2005), h. 215-216.

${ }^{28}$ Para penganut ideologi khilafah, misalnya, banyak berasal dari kalangan terdidik-terpelajar yang berprofesi sebagai dosen di PT umum seperti ITB, IPB, UNAIR, UNESA, dan seterusnya. Para aktivis yang berasal dari PT umum ini biasanya tidak menjalani pendidikan agama di pesantren tradisional, tetapi mereka mendapatkan ilmu agama dari usaha otodidak ketika mereka dewasa. Tidak jarang kebanyakan dari mereka adalah kelompok militan yang "terlahir kembali" menjadi Muslim (reborn Muslim). Lihat, Martin van Bruinessen, "Genealogies of Islamic Radicalism in post-Suharto Indonesia," dalam South East Asia Research, Vol. 10, No. 2 (2002), h. 131-34.
} 
terhadap kelompok radikal. Ketika kasus konflik agama berkecamuk di Ambon dan Poso, misalnya, keterlibatan agen-agen negara, terutama aparat keamanan, dalam pusaran konflik bukanlah hal yang luar biasa. ${ }^{29}$ Aparat keamanan dari pihak kelompok agama yang terlibat dalam konflik mendukung kelompoknya masing-masing dengan cara mempersenjatai kelompok sipil untuk berperang. Para kombatan dari masing-masing pihak dibiarkan membobol gudang senjata yang ada di markas-markas kepolisian yang ada di daerah konflik. Akibatnya, para kombatan dapat mengakses senjata api secara leluasa dan menggunakannya dalam konflik tersebut. Hal ini dibuktikan melalui peredaran senjata api yang begitu masif pada masa-masa konflik di kedua daerah tersebut. ${ }^{30}$

Pelarangan negara terhadap aktivitas radikalisme baru muncul setelah fenomena NIIS. Sebagaimana diketahui, NIIS dinyatakan dilarang di Indonesia berdasarkan Peraturan Pemerintah Pengganti Undang-undang (Perppu). Dalam kasus pelarangan ISIS, negara tidak berpijak pada UU antiterorisme. UU ini tidak bisa digunakan untuk melarang wacana atau ideologi radikal yang akhir-akhir ini berkembang secara leluasa di ruang publik. UU ini hanya bisa menjangkau akibat tindakan yang dilakukan oleh para teroris. Aparat keamanan baru bisa menangkap pelaku radikalisme hanya ketika ada bukti-bukti konkret yang bersangkutan terlibat dalam aksi-aksi kekerasan tertentu. Oleh karena itu, segala peraturan perundangan seperti disebutkan di atas tidak bisa melarang eksistensi figur atau ormas-ormas radikal yang mengusung ideologi atau wacana khilafah, jihad, dan semacamnya. Bahkan banyak di antara mereka yang secara terbuka mendeklarasikan diri hendak mengganti demokrasi dan Pancasila dengan ideologi radikal seperti negara syari'ah atau negara khilafah dan semacamnya.

Di Indonesia, kebijakan negara terkait penanganan radikalisme dan terorisme banyak mengalami resistensi dari sebagian ummat Islam, khususnya dari kalangan radikal sendiri, mengingat upaya penumpasan kelompok radikal hanya didasarkan pada satu pendekatan saja, yakni melalui pendekatan keamanan (security approach). ${ }^{31}$ Kritisisme kelompok radikal didasarkan pada kenyataan banyaknya anggota kelompok radikal yang diperlakukan secara sewenang-wenang, bahkan tidak jarang berakhir pada kekerasan dan penembakan. Para pengeritik berargumen bahwa kebijakan seperti ini tidak akan mungkin bisa menumpas ideologi radikalisme. Lebih jauh, pendekatan keamanan yang bertumpu pada kekerasan negara bahkan penembakan hanya akan melahirkan resistensi

${ }^{29}$ Bambang Pranowo, "Motivation and Root-causes of Terrorism in Indonesia," makalah disampaikan dalam seminar Nasional tentang "Radikalisme Agama dalam Perspektif Global dan Nasional," UIN Syarif Hidayatullah Jakarta, 11 Juni 2015.

${ }^{30} \mathrm{John}$ T. Sidel, "The Manifold Meanings of Displacement: Explaining Inter-Religious Violence, 1999-2001," dalam Eva-Lotta E. Hedman (ed.), Conflict, Violence, and Displacement in Indonesia (Cornell, Ithaca: South East Asia Program Publications, 2008), h. 53.

${ }^{31}$ Masdar Hilmy, "The Politics of Retaliation: the Backlash of Radical Islamists against Deradicalization Project in Indonesia," dalam Al-Jami'ah, Vol. 51, Number 1, 2013/21434, h. 129-158). 
dan perlawanan balik dari kelompok radikal. Mereka bahkan menjadikan Densus 88 Antiteror secara khusus, dan polisi secara umum, sebagai target kemarahan dan balas dendam kaum radikal yang sudah banyak menembak sesama kelompok radikal. Sejumlah penembakan terhadap polisi di beberapa daerah seperti Solo, Jakarta dan lainnya merupakan manifestasi dari bentuk perlawanan dan balas dendam kelompok radikal dimaksud. ${ }^{32}$ Mereka mengelompokkan seluruh polisi sebagai musuh Allah yang harus dilawan. Mereka tidak lagi melihat secara jernih kelompok mana dari kepolisian yang telah bertanggungjawab dalam aksi-aksi penumpasan kaum radikal atau teroris.

Selain melalui security approach melalui Densus 88, memang ada program deradikalisasi melalui Badan Nasional Penanggulangan Terorisme (BNPT). ${ }^{33}$ Namun demikian, eksistensi lembaga ini juga banyak menerima kritikan. Salah satu kritik terhadap eksistensi BNPT adalah tidak jelasnya cakupan kerja dan bentuk-bentuk program yang tidak menjadikan kelompok radikal sebagai target utama. Pelaksanaan program lebih banyak bersifat sporadis, tidak terarah, dan berlangsung di sejumlah domain yang justru tidak terpapar ideologi radikalisme seperti di pesantren-pesantren tradisional. Kritik sejumlah kalangan terhadap lembaga ini memang layak dijadikan sebagai bahan refleksi bagi peningkatan kualitas kebijakan deradikalisasi yang dilakukan oleh BNPT. Jika tidak, maka eksistensi lembaga ini tidak akan menyelesaikan masalah, tetapi justru menambah daftar masalah. Pembentukan lembaga-lembaga ini hanya dianggap sebagai pemborosan anggaran negara yang tidak memiliki agenda dan program yang jelas. Sebaliknya, lembaga-lembaga ini justru dianggap melakukan pembelahan dan pelemahan umat Islam dari dalam.

\section{Mengisi Ruang Kosong Undang-undang}

Melihat fenomena gerakan radikalisme yang akhir-akhir ini membuncah ke ruang publik seperti cendawan di musim hujan, maka dipandang perlu merumuskan sebuah kebijakan publik yang dapat mengatasi gerakan radikal di satu sisi, tetapi tidak menutup demokrasi itu sendiri di sisi lain. ${ }^{34}$ Seseorang tentu saja tidak menghendaki pemberlakuan kembali UU Anti-subversi seperti diterapkan pada masa Orde Baru. Pada saat itu, kemerdekaan berpendapat, bersuara dan berkumpul warga negara benar-benar dipangkas. Setiap kali dijumpai wacana atau ideologi radikalisme muncul dari individu atau institusi keagamaan, negara buru-buru melakukan intervensi dengan cara mengancam siapapun yang berpikiran atau berpendapat macam-macam. Selain membungkam hak dan kemerdekaan warga negara untuk berpendapat atau bersuara, UU Antisubversi pada praktiknya lebih banyak diselewengkan oleh rezim berkuasa dalam rangka melanggengkan

${ }^{32}$ Ibid., h. 152

${ }^{33}$ Ibid., h. 142.

${ }^{34}$ Lihat, Masdar Hilmy, "Radikalisme, Demokrasi, dan Pancasila," dalam Kompas, 12 September 2014, h. 7. 
kekuasaannya. Represi negara terhadap kemerdekaan warga seringkali ditunggangi oleh kepentingan-kepentingan politik rezim. Akibatnya, negara mudah sekali menimpakan tuduhan makar atau subversi terhadap individu, institusi, atau pihak tertentu dengan argumentasi mengancam keamanan negara. ${ }^{35}$

Bangsa Indonesia juga tidak ingin mereplikasi Malaysia dalam mengatasi kelompok radikal. ${ }^{36}$ Cara Malaysia menangani kelompok radikal merepresentasikan cara-cara otoritarianisme yang masih sangat kental. Cara-cara seperti ini rawan dengan unsurunsur kepentingan yang tidak mencerminkan kepentingan publik. Selain itu, cara-cara semacam ini hanya akan semakin menjauhkan negara dari prinsip-prinsip demokrasi yang menjanjikan kemer-dekaan berpendapat. Indonesia telah mengalami hal yang sama seperti Malaysia pada masa Orde Baru melalui UU Antisubversi. Dalam konteks sekarang ini, mereplikasi pengalaman Malaysia dalam menangani gerakan radikalisme sama artinya kita kembali ke masa lalu ketika rezim Orba berkuasa. Oleh karena itu, Indonesia harus menempuh jalan-jalan demokratis yang tidak akan merusak demokrasi itu sendiri, karena Indonesia telanjur berada pada tahap point of no return dalam berdemokrasi. ${ }^{37}$

Pada tahap ini, yang dibutuhkan Indonesia dalam menanggulangi gerakan radikalisme adalah peraturan perundangan yang secara spesifik diarahkan untuk melindungi dan mempertahankan eksistensi Pancasila dan UUD 1945. Bentuknya tidak harus persis seperti UU Antisubversi atau ISA di Malaysia, karena kedua UU ini terbukti mengandung kecacatan, salah satu di antaranya adalah menghalalkan otoritas negara untuk memenjarakan seseorang tanpa proses peradilan terlebih dahulu. ${ }^{38}$ Tetapi, yang lebih ditonjolkan dalam UU tersebut adalah penindakan terhadap siapapun yang dianggap telah memenuhi unsur-unsur pidana di dalam merencanakan atau melaksanakan penggulingan Pancasila dan UUD 1945 baik sendirian atau secara bersama-sama. Dengan UU tersebut, kelompok radikal akan berhitung keras untuk melakukan penggalangan atau penyebaran ideologi radikalnya dalam rangka menggulingkan ideologi Pancasila dan UUD 1945.

Pemihakan Indonesia sebagai bangsa terhadap demokrasi bukanlah pemihakan secara langsung. Konsep berdemokrasi dalam konteks Indonesia mestinya dipahami secara integratif sebagai sebuah paket dengan Pancasila dan UUD 1945. Secara anatomis, demokrasi dan Pancasila serta UUD 1945 merupakan flesh-and-blood dalam kehidupan berbangsa dan bernegara yang saling bersenyawa dan melengkapi. Jadi, formula demokrasi afirmatif yang dimaksudkan di sini bukanlah pemihakan terhadap demokrasi

${ }^{35}$ Ariel Heryanto, State Terrorism and Political Identity in Indonesia: Fatally Belonging (New York: Routledge, 2006), h. 106-34.

${ }^{36}$ Lebih jauh tentang radikalisme di Malaysia, lihat, Joseph Chinyong Liow, Piety and Politics: Islamism in Contemporary Malaysia (Oxford \& New York: Oxford University Press, 2009).

${ }^{37}$ Masdar Hilmy, "Jalan Terjal menuju Demokrasi," dalam Kompas, 11 Mei 2005, h. 4.

${ }^{38}$ Human Rights Watch, "Detained without Trial: Abuse of Internal Security Act Detainees in Malaysia," Vol. 17, No. 9 (September 2005) (diakses dari http://www.hrw.org/reports/2005/ malaysia0905/malaysia0905.pdf, 13 Juni 2015). 
itu sendiri, tetapi pemihakan demokrasi terhadap Pancasila dan UUD 1945 sebagai landasan ideologis dan konstitusional dalam kehidupan berbangsa dan bernegara. Sistem demokrasi akan tegak dengan sendirinya manakala eksistensi Pancasila dan UUD 1945 ditegakkan. Hal ini dapat dipahami karena dari kedua sumber bernegara itulah terdapat turunan peraturan per-undangan yang dapat menciptakan dan menopang iklim demokrasi di negeri ini. Berbagai peraturan perundangan tentang politik dan tata-negara yang dimiliki di republik ini tentu saja tidak bisa dilepaskan dari kedua peraturan perundangan tertinggi di atas.

Dalam konstruk negara hukum, Indonesia sebenarnya telah memiliki perangkat perundangan yang mengatur perihal tindak pidana teorisme melalui UU No. 15 Tahun 2003. UU ini muncul sebagai respon terhadap serangkaian aksi terorisme yang diusung oleh ideologi radikalisme, terutama bom Bali I tahun 2002 yang menewaskan 200 orang lebih. Dilihat secara teleologis, sebenarnya ratio legis perumusan UU tersebut adalah kekerasan teroristik yang dilakukan oleh kelompok radikal. Pasal-pasal yang ada di dalamnya mengatur tindakan kekarasan teroristik dan dampak hukumnya, bukan berisi pelarangan ideologi radikalisme. Dengan demikian, UU No. 15 Tahun 2003 sama sekali tidak bisa menjangkau hasutan atau ajakan seseorang untuk menganut paham radikalisme. Sementara itu, kepenganutan terhadap ideologi radikalisme jelas berangkat dari ajakan seseorang kepada calon penganut melalui argumentasi-argumentasi ideologis dan teologis yang dapat menawan pikirannya. Di sinilah terdapat ruang kosong perundangan yang harus diisi dalam rangka melakukan pencegahan penyebaran ideologi radikalisme di Indonesia tanpa mengabaikan prinsip-prinsip demokrasi.

Perangkat perundangan lain dalam rangka menjerat pelaku terorisme adalah UU No. 9 Tahun 2013 tentang Pencegahan dan Pemberantasan Tindak Pidana Pendanaan Terorisme. UU ini muncul sebagai antisipasi penggalangan dana yang dilakukan oleh kelompok radikal yang sebelumnya tidak ter-cover dalam UU No. 15 Tahun 2003. Seperti biasa, kemunculan sebuah UU merupakan respons terhadap fenomena mutakhir yang tidak terakomodasi dalam peraturan perundangan sebelumnya. Begitu juga dengan UU No. 9 Tahun 2013, di mana ternyata terdapat aliran dana-baik di dalam negeri maupun dari dan ke Indonesia-yang digalang oleh kelompok radikal untuk mendanai berbagai aktivitas radikalisme-terorisme. Sebagai sebuah peraturan yang secara khusus diciptakan untuk mengantisipasi pendanaan terorisme, UU ini, sekali lagi, tidak mengatur pelarangan penyebaran ideologi radikalisme-terorisme yang belakangan ini semakin marak di kalangan masyarakat luas. Jika tidak diantisipasi melalui sebuah UU, maka pelarangan ideologi radikalisme-terorisme tidak akan bisa berjalan secara efektif. Dalam konteks ini, Perppu tentang pelarangan NIIS tidak akan mampu membendung penyebaran ideologi radikalisme-terorisme di Indonesia.

Kenyataan semacam di atas terjadi ketika aparat keamanan tidak mampu menjerat Abu Bakar Ba'asyir atas tuduhan menjadi mastermind di belakang sejumlah aksi kekerasan 
dan pemboman di beberapa daerah beberapa saat yang lalu. ${ }^{39}$ Sekalipun aparat mengetahui bahwa dialah yang berada di balik sebagian besar peristiwa radikalisme dan terorisme di Tanah Air, namun perangkat keamanan tidak bisa berbuat apa-apa karena kekosongan hukum dimaksud. Alasan penangkapan sebagaimana dikemukakan oleh aparat kepolisian adalah terkait dengan pemalsuan dokumen imigrasi, bukan karena ideologi radikalnya. ${ }^{40}$ Hal yang sama juga terjadi ketika aparat keamanan tidak bisa menangkap para simpatisan dan pengikut gerakan NIIS. ${ }^{41}$ Aparat baru benar-benar bisa bergerak jika terdapat buktibukti fisik terkait dukungan mereka pada NIIS seperti bendera hitam berlambang tulisan syahadat, bahan-bahan peledak, bahan-bahan tertulis tentang jihad dan cara-cara merakit bom, dan semacamnya. Penangkapan terhadap aktivis NIIS didasarkan pada Perppu yang keberadaannya secara legal tidak sekokoh UU. Untuk itu, diperlukan sebuah UU yang diharapkan bisa menyempurnakan UU No. 15 Tahun 2003 tentang Tindakan Pidana Terorisme dan UU No. 9 Tahun 2013 tentang Pencegahan dan Pemberantasan Tindak Pidana Pendanaan Terorisme.

Jika dilihat dari perspektif kaum radikal, salah satu argumentasi mengapa mereka menolak demokrasi, Pancasila dan UUD 1845 memang karena ketiganya dianggap sebagai hasil ciptaan manusia. Sementara itu, negara khilafah dan Syariah dianggap sebagai representasi sistem politik-bernagara autentik yang berasal dari wahyu Tuhan yang terekam dalam kitab suci (al-Qur'an dan Hadis). Ketika mereka mengajukan hal-hal yang tertuang secara eksplisit dalam kitab suci, tentu saja mereka tidak mengindahkan dimensi dan relevansi kesejarahan sebagai salah satu aspek penting dalam pengambilan keputusan hukum. Mereka juga tidak melakukan pencernaan kognitif bahwa nilai-nilai yang dikandung oleh demokrasi, Pancasila, dan UUD 1945 pada hakikatnya tidak bertentangan, bahkan sejalan, dengan nilai-nilai Islam. ${ }^{42}$ Dalam konteks inilah, upaya penyadaran, advokasi dan pendampingan secara simultan, serius dan terstruktur perlu dilakukan dalam rangka memahamkan kelompok radikal bahwa di dalam ketiganya terdapat nilai-nilai Islam yang tidak perlu lagi diformalkan melalui struktur perundangan.

\section{Penutup}

Dari penjelasan di atas dapat diambil beberapa refleksi pemikiran berikut ini. Pertama, Indonesia adalah negara demokrasi yang harus setia terhadap prinsip-prinsip negara demokrasi.

39"TPM: Isyarat Penangkapan Ba'asyir sudah Lama," dalam Tempo.com, 9 Agustus 2010 (diakses dari http://nasional.tempo.com/read/news/2010/08/09/063269729/TPM-IsyaratPenangkapan-Baasyir-Sudah-Lama/18, 13 Juni 2015). Baca juga, "Polri Jelaskan Alasan Ba'asyir Ditangkap," dalam BBC Indonesia, 9 Agustus 2010 (diunduh dari: www.bbc.co.uk, diakses 3 Desember 2014).

${ }^{40} \mathrm{Ibid}$.

${ }^{41}$ Hilmy, "Genealogi dan Pengaruh," h. 418.

${ }^{42}$ Masdar Farid Mas'udi, Syarah UUD 1945 Perspektif Islam (Ciputat: Pustaka Alvabet \& Lembaga Kajian Islam \& Perdamaian [LaKIP], 2013). 
Kebijakan penanganan terhadap gerakan radikalisme harus berada dalam kerangka demokrasi dan tidak boleh mengorbankan prinsip-prinsip demokrasi dimaksud. Indonesia tidak boleh mereplikasi cara-cara otoriter yang ditempuh oleh negara-negara "disipliner" seperti Malaysia yang lebih memilih mengorbankan nilai-nilai demokrasi demi stabilitas ekonomi-politiknya. Sekalipun demikian, kebebasan berpendapat yang diamanatkan oleh demokrasi tidak boleh menyebabkan negara lemah atau terlemahkan. Negara sepenuhnya memiliki otoritas untuk mengambil kebijakan tegas (tetapi tetap dalam bingkai negara demokrasi) untuk mengatasi gerakan radikalisme agama.

Kedua, Indonesia (dalam bingkai negara demokrasi) harus merumuskan sebuah produk peraturan perundangan yang mengatur bagaimana setiap warga negara memelihara kebebasan berpendapat, termasuk dalam hal ini adalah kebebasan untuk memiliki paham keagamaan radikal. Setiap individu tidak dilarang untuk memiliki paham keagamaan radikal sepanjang yang bersangkutan tidak menggalang kekuatan atau dukungan untuk menumbangkan Pancasila dan UUD 1945. UU baru tersebut diharapkan dapat mengisi ruang kosong dalam peraturan perundangan kita sekaligus menyempurnakan UU No. 15 Tahun 2003 tentang Pemberantasan Tindak Pidana Terorisme dan UU No. 9 Tahun 2013 tentang Pencegahan dan Pemberantasan Tindak Pidana Pendanaan Terorisme. UU baru tersebut tidak melarang seorang warga negara untuk memiliki pikiran, paham dan ideologi keagamaan apapun, sepanjang tidak diarahkan untuk menggalang kekuatan dalam rangka menumbangkan Pancasila dan UUD 1945.

\section{Pustaka Acuan}

Beetham, David. "The Quality of Democracy: Freedom as the Foundation," dalam Journal of Democracy, Vol. 15, No. 4, October 2004.

Blokland, Hans. Freedom and Culture in Western Society. London: Routledge, 1997.

Crouch, Melissa. "Religious Regulations in Indonesia: Failing Vulnerable Groups," dalam Review of Indonesian and Malaysian Affairs, Vol. 43, No. 2, 2009.

Fuller, Graham E. The Democracy Trap: the Perils of the Post-Cold War World. Boston: Dutton, 1992.

Hasan, Noorhaidi. Laskar Jihad: Islam, Militancy, and the Quest for Identity in Post-New Order Indonesia. Ithaca: Cornell Southeast Asia Program Publications, 2006.

Hefner, Robert W. Civil Islam. Princeton: Princeton University Press, 2000.

Heryanto, Ariel. State Terrorism and Political Identity in Indonesia: Fatally Belonging. New York: Routledge, 2006.

Hilmy, Masdar. “"Quo-Vadis” Kebebasan Beragama?,” dalam Kompas, 1 Maret 2011, 7.

Hilmy, Masdar. "Genealogi dan Pengaruh Ideologi Jihadisme Negara Islam Iraq dan Suriah (NIIS) di Indonesia," dalam Teosofi, Vol. 4, Nomor 2, Desember 2014.

Hilmy, Masdar. "Radikalisme, Demokrasi, dan Pancasila," dalam Kompas, 12 September 2014. 
MIQOT Vol. XXXIX No. 2 Juli-Desember 2015

Hilmy, Masdar. Islamism and Democracy in Indonesia: Piety and Pragmatism. Singapore: ISEAS, 2010.

Hosen, Nadirsyah. "Human Rights and Freedom of the Press in the post-Soeharto Era: A Critical Analysis," dalam Asia Pacific Journal on Human Rights and the Law, Vol. 3, No. 2, 2002.

Human Rights Watch. "Detained without Trial: Abuse of Internal Security Act Detainees in Malaysia," dalam http://www.hrw.org/reports/2005/malaysia0905/ malaysia0905.pdf, 13 Juni 2015).

Human Rights Watch. "In the Name of Security: Counterterrorism and Human Rights Abuses under Malaysia's Internal Security Act," Vol. 16, No. 7, Mei 2004.

Huntington, Samuel P. The Clash of Civilization and the Remaking of World Order. New York: Penguin Books, 1996.

Kekic, Laza. "The Economist Intelligence Unit's index of democracy," dalam http:// www.economist.com/media/pdf/DEMOCRACY_INDEX_2007_v3.pdf.

Lawrence, Bruce B. Defenders of God: The Fundamentalist Revolt against the Modern Age. San Francisco: Harper \& Row, 1989.

Lev, Daniel S. "Judicial Authority and the Struggle for an Indonesian Rechtsstaat," dalam Law and Society Review, Vol. 3, No. 1, Autumn, 1978.

Liow, Joseph Chinyong. Piety and Politics: Islamism in Contemporary Malaysia. Oxford \& New York: Oxford University Press, 2009.

Mas'udi, Masdar Farid. Syarah UUD 1945 Perspektif Islam. Ciputat: Pustaka Alvabet \& Lembaga Kajian Islam \& Perdamaian [LaKIP], 2013.

Mousalli, Ahmad S. Radical Islamic Fundamentalism: The Ideological and Political Discourse of Sayyid Qutb. Beirut: American University of Beirut, 1992.

Pranowo, Bambang. "Motivation and Root-causes of Terrorism in Indonesia," makalah disampaikan dalam seminar Nasional tentang "Radikalisme Agama dalam Perspektif Global dan Nasional," UIN Syarif Hidayatullah Jakarta, 11 Juni 2015.

Przeworski, Adam, et. al., Sustainable Democracy. Cambridge: Cambridge University Press, 1995.

Reardon, Lawrence C. “Interpreting Political Islam's Challenge to Southeast Asia: International Terrorism, Nationalism, and Rational Choice," dalam William Crotty (ed.), Democratic Development and Political Terrorism: The Global Perspective. Florida: Northeastern University Press, 2005.

Roy, Olivier. The Failure of Political Islam. Massachusetts: Harvard University Press, 1996.

Sen, Amartya. "Democracy as a Universal Value," dalam Journal of Democracy, Vol. 10, No. 3, 1999.

Sidel, John T. "The Manifold Meanings of Displacement: Explaining Inter-Religious Violence, 1999-2001," dalam Eva-Lotta E. Hedman (ed.), Conflict, Violence, and 
Displacement in Indonesia. Cornell, Ithaca: South East Asia Program Publications, 2008: 29-60.

Thoolen, Hans. Indonesia and the Rule of Law: Twenty Years of "New Order" Government: a Study. London: Pinter Pub Ltd., 1987.

van Bruinessen, Martin. "Genealogies of Islamic Radicalism in post-Suharto Indonesia," dalam South East Asia Research, Vol. 10, No. 2, 2002.

Wildan, Muhammad. "Mapping Radical Islam: A Study of the Proliferation of Radical Islam in Solo, Central Java," dalam Martin van Bruinessen (ed.), Contemporary Developments in Indonesian Islam: Explaining the "Conservative Turn". Singapore: ISEAS, 2013.

"Polri Jelaskan Alasan Ba'asyir Ditangkap," dalam www.bbc.co.uk, 3 Desember 2014.

"TPM: Isyarat Penangkapan Ba'asyir sudah Lama," dalam http://nasional.tempo.co/ $\mathrm{read} /$ news/2010/08/09/063269729/TPM-Isyarat-Penangkapan-Baasyir-SudahLama/18, 13 Juni 2015.

http://www.id.undp.org.

https://freedomhouse.org. 